\title{
Impacted Factors of Academic Achievement of the Timorese Student Studying in Indonesia
}

\author{
Augusto da Costa \\ Instituto Superior Crystal, Timor-Leste \\ acostas3bk2015@gmail.com \\ Fattah Hanurawan \\ State University of Malang, Indonesia \\ fhanurawan@yahoo.com
}

\author{
Adi Atmoko \\ State University of Malang, Indonesia \\ dias_65@yahoo.co.id \\ Imanuel Hitipeuw \\ State University of Malang, Indonesia \\ imanuel.hitipeuw.fip@um.ac.id
}

\author{
Nur Hidayah \\ State University of Malang, Indonesia \\ nurhidayahum@yahoo.com
}

\begin{abstract}
The purposes of this study is to explore those two impacted factors of academic achievement of the student of Timor Leste who are staying in Indonesia. These factors are academic behavior and extrinsic motivation. The method which was used to analysis the data was multiple regression. The research involved those 4.450 Timorese student in Indonesia, the sample were 300 student that was determined with multistage cluster random sampling. The data been collected with Likart Scale which was distributed directly to the samples. Data being analysis with multiple regression. The result of shown that there were $4 \%$ highest, $52 \%$ were high, $25 \%$ are medium and 19\% are low. In regarding to the impact academic behavior, extrinsic learning motivation on academic achievement shown that academic behavior are $35.8 \%$ on academic achievement, Extrinsic leaning motivation are $54,1 \%$ on academic achievement of Timorese student, who are studying in Indonesia.
\end{abstract}

Keywords: academic achievement, academic behavior, intrinsic motivation

\section{INTRODUCTION}

Timor Leste was declared to be independent country the early of 21 st centuries. As newest country in the Asia region Timor Leste needs a lot of resources to construct and to develop the country, specially human resources to explore and to use the natural resources as much as possible (Thomas, 2005; Gijzen, 2014; Lucas et.al., 2015). High quality of the human resources will be reached by education. Good quality of education system is needed to elevate human resources of the Timorese student. It means the government has fully responsibility to create all possibilities to develop as much as possible the opportunity and facilities to increase and strength education system that has been existed in Timor Leste, and the opportunity be given to every single citizen to develop its self though formal and non-education (Const. 59).

However, as newest country, Government are still struggle to accommodate and to provide the standard facilities and standard of education system (Governo, 2010). Therefore Government needs to cooperate with the neighborhood country in various aspects, including education. One of the neighboring country that really help Timorese government in education area is Indonesia. Timorese government has been cooperated with the Indonesia since 2002. The reason of this cooperation was to develop the quality of human resources of the Timorese student.

The fact of the quality of human resources has being expressed in academic achievement and graduated on time. Based on the previous study that some Timorese student were graduated on time by standard and high academic achievement, however, the fact that $37.9 \%$ of student were graduated overdue means they need one or more extra semester before graduating, those student normally has low academic achievement (Da Costa, 2015). Those fact should be good handle if there are guidance and counseling services at every stage of the education. Unfortunately, until this moment there are not integrated guidance and counseling services yet into formal education system.

In regard of this mater, there is main question that needs to be addressed in this research. What is the quality of academic achievement? What is factors that impact on the academic achievement? Therefore this study needs to be conducted to explore the factors that impacted on those facts. The Participant of this study was 4.450 Timorese Student who are spreading throughout of Indonesian main education city such as all the province in Java, Bali and Nusa Tenggara Timur (NTT), the 300 sample was determined with multistage cluster random sampling. The academic achievement be taken was index achievement cumulative of all the semester that has been achieved till 2016/2017.

This study conducting in regards to explore the variables that impact on academic achievement such as academic behavior and extrinsic motivation. Based on the description in background should be formulated five problems: (1) what academic achievement is? (2) what academic behavior is? (3) what extrinsic motivation is? (4) how academic behavior and extrinsic motivation should impact on academic motivation? And (5) how guidance and counseling services should play its rule in education system?

\section{Participant}

\section{METHODS}

The population of this research are entire Timorese student, who are studying at various institute 
and university in Indonesia. At previous semester, there are 4.450 Timorese student. The sample 300 been taken with multistage cluster random sampling (Creswell, 2015). The sample been asked to print out their academic report from the first semester up to previous semester at academic year 2016/2017.

\section{Instrument}

The instrument that be using to collect the date was academic behavior scale and extrinsic learning motivation scale. In regards to academic achievement was the result of the academic report of each semester. To complete the data $d$ been conducted also observation and documentation. Observation been done when researcher attended national celebration in Jakarta on May 2017, which 500s Timorese student involved in.

There were four momentum that including Timorese student in Java-Bali for instance sport, seminar and Mass and celebration of the independent day. For the Kupang area been visited twice to the office of the Timorese association in Kupang to meet with the sample and the member of executive body.

Also, been done documentation such as academic report of the each semester that been done by sample student and scale of each independent variable in this research. Actually all the official instrument combine of 6 variables, which composed of 40 point of scale. Getting these 40 point scale after having field experiment and expert test from 98 point.

However at this article research only take three variables to formulate this report. Scale of academic behavior combine of 12 point and extrinsic learning motivation are 6 point. It means all instrument of this two variables are 18 point.

\section{Procedure}

The procedure that used in this research after having instrument bee ready. The official letter for researching be organized from Universitas Negeri Malang (UM). The permission letter valid for 6 month from March to September 2017.

The letter address to Timorese Embassy in Jakarta, especially education department and all the president of Timorese student association in each province. Information and letter be sent to those has right to get the research official letter and determining time table to visit each provinces.

Meeting with sample conducted to explain the procedure of filling scale beforehand sample has been asked to bring the copy of academic report. After sample understand the procedure of filling scale then, the scale be distributed to each sample that present and willing to take part of this research.

Duration time to fill scale was varieties, between 30 - 40 minutes per sample. The concluding stage sample be offered simple lunch as sign of gratitude for their good willing to help. Those simple reward be given at the end of session to avoid bias in answering the scale. The next stage after getting data was tabulation, screening, analyzing the data with SPSS 24 for Windows and with the method multiple regression.

\section{Academic Achievement}

\section{RESULT}

The result of the academic achievement were taken from the GPA of the each sample academic report of all thee semester that has been reached. From 300 sample be categorized into three group such as high, medium and low level academic achievement. Highest level academic achievement are those samples got value between $3.51-4.00$, are 12 sample means $4 \%$, High level academic achievement are those samples got value between $2.76-3,50$ are 154 samples mean 52\%; medium level academic achievement are those samples got value between $2.50-2,75$ are 75 samples mean $25 \%$. Low academic achievement are those samples got values between $1.00-2.47$ are 58 sample means $19 \%$.

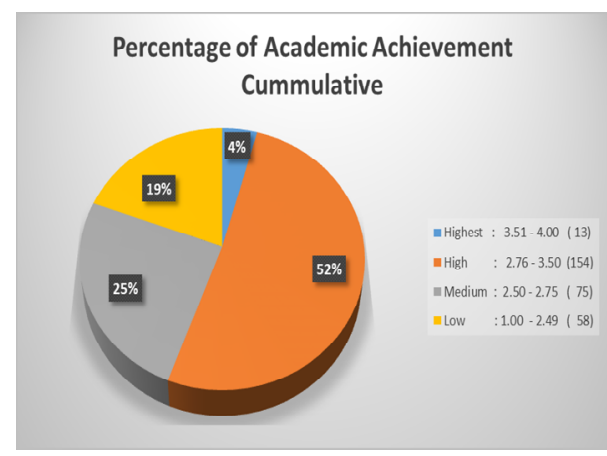

Figure 1

Percentage of academic achievement accumulative

Based on the picture above show the clear map of academic achievement of Timorese student, who are studying in Indonesia. There are $4 \%$ who got highest values of academic achievement cumulative. The high values of academic achievement cumulative be achieved by $52 \%$. Those who are getting medium marks are $25 \%$ and $19 \%$ are low academic achievement. Those low academic achievement if compare with the highest or high level achievement this percentage situated in concerning level because percentage is significantly high. If $19 \%$ be combined with the medium one $(25 \%)$ it will become $44 \%$, means almost half samples are in low and medium. This this fact need to be put into consideration Timorese government who are in charging in education area.

\section{Impact Academic behavior and Extrinsic Learning Motivation on Academic Achievement}

Based on the table of model summary the values of $\mathrm{R}$ are .829 shows that correlation between academic behavior, extrinsic learning motivation on academic achievement are high (between 0.8 to 0.9 ) (Table 1). The values R Square are .687. It means that $68,7 \%$ Varian of academic achievement can be explained by both independent variables. Meanwhile the rest $(100 \%-68.7 \%=31.3 \%)$ be explained by the other causes. Standard error of estimate (SEE) are 3.895 means the error in predicting academic achievement with both variables in the future are 4 . 
Table 1

Output Model Summary

\begin{tabular}{|c|c|c|c|c|c|c|c|c|c|}
\hline \multicolumn{10}{|c|}{ Model Summary } \\
\hline \multirow[b]{2}{*}{ Model } & \multirow[b]{2}{*}{$\mathrm{R}$} & \multirow[b]{2}{*}{ R Square } & \multirow[b]{2}{*}{$\begin{array}{ll}\text { Adjusted } & \mathrm{R} \\
\text { Square } & \end{array}$} & \multirow[b]{2}{*}{$\begin{array}{l}\text { Std. Error of } \\
\text { the Estimate }\end{array}$} & \multicolumn{5}{|l|}{ Change Statistics } \\
\hline & & & & & $\begin{array}{l}\mathrm{R} \text { Square } \\
\text { Change }\end{array}$ & F Change & df1 & df2 & $\begin{array}{l}\text { Sig. } \\
\text { Change }\end{array}$ \\
\hline 1 & $.829^{\mathrm{a}}$ & .687 & .685 & 3.895 & .687 & 325.606 & 2 & 297 & .000 \\
\hline
\end{tabular}

Table 2

Output of ANOVA

\begin{tabular}{|l|l|l|l|l|l|l|}
\hline \multicolumn{7}{|c|}{ ANOVA $^{\mathrm{a}}$} \\
\hline Model & Sum of Squares & df & Mean Square & F & Sig. \\
\hline \multirow{4}{*}{1} & Regression & 371809.359 & 2 & 185904.679 & 325.606 & $.000^{\text {b }}$ \\
\cline { 2 - 7 } & Residual & 169572.278 & 297 & 570.950 & & \\
\cline { 2 - 7 } & Total & 541381.637 & 299 & & & \\
\hline
\end{tabular}

Table 3

Output of Coefficients

\begin{tabular}{|c|c|c|c|c|c|c|}
\hline \multicolumn{7}{|c|}{ Coefficients $^{\mathrm{a}}$} \\
\hline \multirow{2}{*}{\multicolumn{2}{|c|}{ Model }} & \multicolumn{2}{|c|}{ Unstandardized Coefficients } & \multirow{2}{*}{$\begin{array}{l}\text { Standardized Coefficients } \\
\text { Beta }\end{array}$} & \multirow[b]{2}{*}{$\mathrm{t}$} & \multirow[b]{2}{*}{ Sig. } \\
\hline & & $\mathrm{B}$ & Std. Error & & & \\
\hline \multirow[t]{3}{*}{1} & (Constant) & 153.912 & 5.293 & & 29.077 & .000 \\
\hline & $\mathrm{AB}$ & 1.540 & .192 & .358 & 8.017 & .000 \\
\hline & ELM & 5.109 & .421 & .541 & 12.125 & .000 \\
\hline
\end{tabular}

Table 4

Summary Output Coefficient

\begin{tabular}{|c|c|c|c|c|}
\hline Dependent & \multicolumn{3}{|c|}{ Summary Coeficience regression } & \multirow{2}{*}{$\begin{array}{l}\text { Modeling equation regrassion } \\
\mathrm{Y}=\text { Constant }+\beta 1 \mathrm{X} 1+\beta 2 \mathrm{X} 2\end{array}$} \\
\hline & \multirow[t]{2}{*}{ Constant } & Beta & & \\
\hline & & $\mathrm{X} 1$ & $\mathrm{X} 2$ & \multirow[t]{2}{*}{$\mathrm{Y}=153.912+.358+541$} \\
\hline & 53.912 & .358 & .541 & \\
\hline
\end{tabular}

Result of Anova tested shown that the F-test 325.606 by significance 0.000 which is less than 0.05 , it means regression model worthy been used to predict academic achievement (Table 1). Therefore variable academic behavior and Extrinsic learning motivation both significant impact on academic achievement of Timorese student, who are studying in Indonesia. This output is used to know contribution of academic behavior and extrinsic learning motivation to academic achievement (Table 4).

Based on the Table 4 be known that content are 153.912. These score shows that if without academic behavior and extrinsic learning motivation means academic achievement be predictive between 53.912. Coefficient regression $\mathrm{X} 1$ are .358 shows that variable academic behavior contribute to academic achievement are $35.8 \%$. It means each addition $(+)$ one score academic behavior which obtained at previous semester by Timorese student will increase academic achievement predictive on $35.8 \%$ of values that has been achieved at previous moment. Coefficient regression $\mathrm{X} 2$ are .541 shows that variable extrinsic learning motivation contribute to academic achievement are $54.1 \%$. It means each addition (+) one score academic behavior which obtained at previous semester by Timorese student will increase academic achievement predictive on $54.1 \%$ of values that has been achieved at previous moment.

\section{DISCUSSION}

Mirroring on the description and analysis above there are some points that needs to be discussed further in answering the problems of research. All the answering to those questions has been addressed though descriptions and analysis on the data research. However, in facing and dealing with academic achievement GPA there are some concern that drawn more attention and more energy of Timorese government in handling curriculum and education system in Timor Leste, especially in Primary and secondary school.

Timorese government must more invest in education to elevate students' human recourse since primary and secondary school. Because the date of the research shows that GPA of Timorese student, who are studying in Indonesia. Some of those student were getting medium marks are $25 \%$ and $19 \%$ are low academic achievement. If these medium and low percentage of academic achievement be combine it would be come $44 \%$ of the samples. For preventing this fact from now Timorese government need to integrate guidance counseling service into curriculum and education system in Timor Leste. Guidance and counseling service accompany, to guide and help all student at every stage of their education, especially at Primary and secondary level to discover their own ability and potency, and capacity in growing and developing to be fully human being in all aspect of 
their life (Depdiknas, 2008). It means guidance and counseling service will help all student in facing and dealing with all challenges that they have as student in the family, school and in large society.

The fact the there are no school counselor, who are really qualified and expert in guidance and counseling program. Those who acts as school counselor are senior teachers in the school or some sisters that has skill of education psychology, but not really counselor in se. Early this year tall the catholic school in Timor Leste send a group of teachers and some priest to Sanata Darma University to take counseling course for 3 month.

\section{Understanding, Rules and Factors of Academic Achievement}

Academic achievement is a form of level of mastery of knowledge and skills that students achieve on the subject matter to achieve the goal. Academic achievement understood in 2 academic achievement and academic performance concepts is measured by the results of the yearly semester, weekly, and attendance quiz tests in the course (Ali et al., 2009; Farooq et.al. 2011; Gani et.al, 2012). Academic performance is the ability of students in completing tasks with grade point achievement in figures and letters, achieved in the previous semester and contribute to the quality standard of education that is the goal of every educational institution (Shah, 2010; Farooq et.al, 2011; Farrington et.al., 2012; Ahmar \& Anwar, 2013; Ganai \& Mir; 2013; Garcia \& Al-Safadi 2014; York, et.al, 2015).

Academic achievement is also understood as a result of student learning through continuous examination and assessment (Academic achievement becomes the key and the essence of further educational determinants and positions in work that are expected by education stakeholders (Farooq et al, 2011; Farrington et al., 2012; Hadi, 2012; Ahmar \& Anwar, 2013; Srisongkhram, 2014; Edgecombe, 2011; Flashman, 2012). Skills that encourage learning behaviors, timing, home-work strategies and skills completion of tasks (). Academic achievement shows the quality of graduation, to become the country's leader in charge of economic and social development (Mushtaq \& Khan, 2012; Laguador, 2013; Bulaklak \& Pilobello, 2014).

Academic achievement is an important factor in the realm of education, especially the development of scholastic students and human resources at the macro level. Academic achievement for students becomes the determinant key for further education and success in work. Academic achievement is the essence of broad educational development. The role of academic achievement for students is an intrinsic factor that indicates students' ability. Records of academic achievement as a pillar for all the future. Means academic achievement to be the center of educational research and there are various definitions of educational goals, academic development becomes the main objective for lecturers (Ali et al, 2009; Flashman, 2012; Ahmar \& Anwar, 2013, Ganai \& Mir, 2013).
The academic achievement achieved in the previous semester becomes the foundation for lecturers and institutions to determine graduation, and the number of credits to be taken in the following semesters. Academic achievement is an expression of the level of knowledge and skills that have been achieved. Students feel proud of themselves, admired fellow, lecturers and parents if obtaining optimal academic achievement. It means that academic achievement becomes a barometer of knowledge and skill level, and a source of pride (Srisongkhram, 2014). Academic achievement is assumed as an essential factor in the education system, progressive scholastic development and human resources that develop at the macro level. Academic achievement becomes the essence of educational goals is very important for educational institutions and students (Biswal \& Aggarwal, 1971) to set the next step.

The academic achievement achieved in the previous semester becomes the foundation for lecturers and institutions to determine graduation, and the number of credits to be taken in the following semesters. Academic achievement is an expression of the level of knowledge and skills that have been achieved. Students feel proud of themselves, admired fellow, lecturers and parents if obtaining optimal academic achievement. It means that academic achievement becomes a barometer of knowledge and skill level, and a source of pride (Srisongkhram, 2014). It means student involve two important factor in their study such as personal and environment factors.

The personal and environment factors are important for the Timorese students are studying in Indonesia, in order to improve their human resources. The process of constructing is accomplished skill and knowledge through the process of cognition is also affected psychological and physical aspects. As has been studied in the background mainly through observation and preliminary studies it was found that East Timorese students in Malang who were involved in $37.9 \%$ preliminary study experienced a delay in completing the study as well as with the achievement of the academic standard of graduation. On the other hand, it was found that some of the Timorese students were studying in Malang were awarded the best graduates in their faculties and universities also.

Behavioral factors in the context of this study that allegedly influenced the academic achievement of Timorese students, who are studying at the universities in Indonesia are the students' physical actions associated with "good students." These aspects include: going to college for college, doing homework in accordance with the lecturers' demands, organizing regular lecture materials to facilitate learning, taking part in every academic moment in and outside campus, using time effectively and efficiently for learning (Mlambo, 2011; Farrington et.al., 2012). It was emphasized two factors such as Academic behavior and extrinsic motivation.

Based on the above study it can be formulated that the academic achievement of Timorese students, who are studying in Indonesia is allegedly influenced by the two factors that have been alluded to in the 
introduction such as academic behavior and extrinsic motivation.

\section{Understanding, Rules, Factors of Academic Behavior and Impacts on Academic Achievement}

Academic behavior is described as a set of skills and action that necessary to succeed in the classroom and in the school environment. This academic behavior directly affects the success of students and students in schools and universities. Academic behavior is a common practice associated with being a "good student" such as attending classes regularly, completing homework, organizing materials regularly to make learning easier, taking part actively in classroom discussions, and using study time to study. Behavior study is the habits, willingness and learning skills possessed by students (Hastuti, 2003; Farrington et.al, 2012). It means academic behavior is student behaviors from self in practicing to be good student in their campus and university plays important roles in the process of their study.

Academic behavior occupies an important place in the consideration of non-cognitive factors because almost all student academic achievements, which include: cognitive, non-cognitive and metacognitive, are expressed through academic behavior. For example completing tasks, participating in class activities, developing and demonstrating the content knowledge and academic skills. If the student really mastered the course material but did not submit the assignment or did not take the exam, the lecturer could not assess the student's ability. Behavior serves is mediator of cognitive and non-cognitive factors that affect student value. Academic behavior is also be understood as the habits, wishes and learning skills that students have. Academic behavior is understood as a repeated student effort that becomes automatic (Conrad, 2006; Farrington et.al, 2012).

Academic behavior combined from 5 factors that facilitate students to achieve educational goals, achieve optimal academic achievement and pass on time. These five factors include: going to class, doing homework, organizing materials, participating and studying (Farrington et.al, 2012). This second thought is used to describe academic behavior and its effect on the academic achievement of Timorese students.

Going to class in question is the actions of students attending the whole process of learning and teaching in their educational institutions. The process is conducted together with educators and fellow students in the scope of internal class activities. Internal factors of the academic class include: student ability in the field of study, class schedule, class size, exam results, learning tools, homework, classroom environment, complexity of subject matter, teacher role in class (Reutzel, 2011; Abdullah et.al., 2012). Classrooms are accepted as the primary environment in learning in educational institutions therefore lecturers should apply the principle of student centered class following the 5 key changes although learning can be done elsewhere (Hill 2007; Weimar, 2013; Fahraeus, 2013; McGahaGarnett, 2013). It means that the lecturer should make the class become the best place for students to achieve their full potential in academic achievement. Students must attend classes according to the schedule that has been decided (Falsario et.al, 2014).

Doing homework is defined as each type of academic activity assigned by the lecturer to the students to be done and completed at home. Assignments can be completed during lectures in the classroom, or any other time (Cooper et al, 2006). Junior / Senior High School teachers are more likely to use homework to prepare students to study before entering the classroom on the grounds of communication, preparation, practice and teaching. This program helps parents to know the academic strengths and weaknesses of their children. Education should use the practice of parental involvement to understand the school environment.

Organizing materials is a student effort to organize lecture materials delivered by lecturers in class and given as a homework assignment. Students should organize academic material well and regularly based on the subject and teaching subject matter of the lecturers, in order to facilitate them in studying and doing homework effectively and efficiently. Furthermore, it is said that teaching is a very complex activity involving careful, hourly, daily, and weekly preparations and plans. Long-term plans refer to the semiannual and annual curriculum (Arnold, 2008). It means that lecturers have high expectation toward the students so that they develop strategies to facilitate the students.

Participating is a student effort in following every academic activity at campus actively, effectively and efficiently. Participate actively in academic activities are inside and outside the classroom. Actively participate in all academic activities during class hours and outside according to curriculum-based schedules,). Academic activities outside of college: attending local, regional, national and international conferences, seminars, workshops and workshops to increase knowledge and skills (Peterson \& Seligma, 2004, Rocca, 2010; Abdullah et.al, 2012; Weimar, 2013).

Studying is an effort to increase knowledge and skills through learning. Repeating the material that has been obtained and looking for material related to the theme of classroom studies. Students are expected to study at any time and place. The time of the lecturer's absence is used to go to the library, or have a scientific discussion related to the lecture material on the day. Spare time is used effectively to improve knowledge and skills. This factor will help students pass on time with optimal academic achievement (Stronge, 2007). All five are the ideal aspect that should be done by every Timorese student to facilitate process of study runs smoothly for achieving the optimal academic achievement and graduate on time.

Based on the above study can be formulated that academic behavior acts as a catalyst awareness of students using every moment effectively and efficiently in learning, and interact directly between students and lecturers. Interacting allows students to capture the lecturer's enthusiasm explaining a topic and can immediately ask if anything is not understood. Means 
that every academic behavior facilitates students to construct and improve their knowledge and skills.

Academic behavior impacts on academic achievement of the students in determining the value. It means academic behavior affects the values and failures, characteristics and background of students: gender, ethnicity, economics, school mobility, and age of admission to university. It is proposed that absences and learning habits affect failure (Allenworth \& Easton, 2007; Farrington et.al, 2012). Absences and learning habits by predicting failure and success in achieving optimal academic achievement so that pass time can be achieved.

Some researchers have shown differences in academic behavior to contribute to gap achievement between different groups, races and gender (Duckworth \& Seligman, 2006). This difference explains some of the gaps. CCSR researchers presented the effect of student attendance and study habits contributing to ethnic and gender differentiation of student values (Allensworth \& Easton, 2007). It seems as if it is difficult to change the habits and personality of the students. But the basic principle of psychology says that it is almost always possible to change behavior (Deci \& Ryan, 1985), herein lies the role of counselor. Almost all educational reform efforts are based on the basic assumption that guidance and counseling services are facilitating students to face and resolve their challenges in learning and in all aspects of life.

The gender gap in the GPA declined $21 \%$ after taking into account student attendance and study habits, and the difference in failure decreased by $1 / 3$. Presence and study habits no racial gaps explain in the classroom, when comparing test scores of students with the same economic status. African American students receive lower grades than white students with similar test scores, attendance and study habits. In his analysis data of more than 10,000 students from the National Longitudinal Study followed by national representatives of samples with eight classes from 1988-1994, (Jacob \& Small, 2003) found small gender differences in academic behavior in eight classes. It was reported that the male students conducted homework 5.87 hours per week compared to female students who spent 6.21 hours per week on PR (difference 0.34 hours per week). That gender differences in behavior decreased to 0.11 hours per week by 12 classes' student, with college students reporting weekly jobs of 9.74 hours and 9.85 hours each. The results of previous studies that examine the influence of learning behavior on the level of understanding of accounting (Nugroho et al, 2011) that there is the influence of learning behavior on academic achievement.

Based on the previous study, it can be concluded that the students have good academic behavior: going to class, doing homework, organizing material, participating and studying, will achieve optimal academic achievement. On the other side, those student who have less academic behavior will obtain minimal academic achievement. Therefore, Timorese student needs to realize that to obtain optimal academic achievement and to reach the target to graduate on time; they need to create a good academic behavior.

\section{Understanding, Rules and Factors of Intrinsic} Motivation and Impacts on Academic Achievement

Extrinsic motivation comes from external values and demands, almost all are driven by environmental contingencies. Extrinsic motivation is an outward impulse to learn with a particular purpose or lead to a particular behavior such as getting a compliment from a lecturer, getting good grades, getting a prize. This means that learning with high motivation will achieve optimal performance or otherwise (Deckers, 2005; Vansteenkiste et.al, 2006; Singh, 2011; Anjomshoa \& Sadighi, 2015; Fen \& Kiat, 2015). Extrinsic learning motivation refers to encouragement, support and outside spirit in the form of rewards, praise and achievement levels. This means extrinsic motivation is an answer that helps students to be more confident in answering questions at the time of the exam. Means extrinsic motivation is an external encouragement in the form of praise and punishment that encourages students to learn to achieve optimal academic achievement. It is also understood that the extrinsic motivation of learning is the spirit of anticipation of external appreciation (Yahaya et.al, 2010; Anjomshoa \& Sadighi, 2015). Means extrinsic learning motivation has important rules in leaning.

Extrinsic learning motivation rules as supporter, encouragement, inspiration, and guide. The support of student actions in learning derived from social life. It means parents, family, fellow students, lecturers and every stakeholder of the institution where the students are studying. The starting point of extrinsic learning motivation in the form of prizes, awards, praise and optimal value received by students to be more diligent and focused in learning. Those extrinsic encouraging are such as money, certificates, achievement levels, high office, which serve as a way to achieve other achievements including academic achievement (Covington \& Mueller 2001; Wang \& Guthrie , 2004; Deckers, 2005; Hilden \& Jones, 2011; Riley, 2016). All of those are extrinsic factors.

Extrinsic factors that shape extrinsic motivation are educational tools, parent and teacher associations, family, teachers, fellow students, environment and language expressions that motivate students in study at each faculty and university. As briefly asserted that external regulatory factors (reward, punishment and value) - values in oneself and others, by recognizing external rules, differentiating, identifying, integrating in student behavior and learning objectives with external consequences (McClelland, 1987, Ryan \& Decci, 2000; Ryan \& Deci, 2009; Yahaya et.al., 2010; Levesque et.al., 2011).

The setting of extrinsic motivation refers to the behavior determined through means outside the individual. Because the drive from outside the individual done only in learning so that the individual cannot survive, even ignoring it when learning is considered difficult (Deci \& Ryan, 2000; Levesque et al., 2011 ) Extrinsic motivation-introjected regulation means that behavior is partially controlled by the 
environment and partly from within the individual such as the individual feels proud, guilty and ashamed. It means that the introjected regulation uses a low level of awareness because of the pressure of dealing with the internal rules of dealing with external (Vallerand et.al., 1992; Levesque et.al, 2011). The identification of external arrangements refers to the actions taken on the basis of individual judgment and choice, meaning that it stirs attention to achieve goals. This factor is independently derived from extrinsic motivation. Integration refers to attached behavior in its entirety with a personal plan. It means that student behavior is regulated through a combination that is fully accepted, with aspects and other values of student life (Vallerand et.al., 1992; Deci \& Ryan, 2000; Levesque et.al, 2011; Areepat-tamannil et.al, 2011). Meaning extrinsic learning motivation has impacted academic achievement.

Extrinsic learning motivation influences the academic achievement of students at the every levels of education. There are several previous research results: (1) been found (Yahaya et al., 2010) that 59\% of students agreed school facilities (school environment, library) motivated them to learn diligently so that optimal academic achievement was achieved. The role of parent and teacher associations affects $69.1 \%$ of the students' academic achievement in Math lessons. Support of the teachers to student were $57.9 \%$ on student academic achievement in Math lessons. There were $57.9 \%$ of students agreed that teachers has played an important role in motivating students to learn Math. $53.2 \%$ of students agree that teachers facilitate them in facing the challenges of teaching and learning. There were $32.4 \%$ of students agree that family was one of the extrinsic motivation factors for them to learn mathematics. Students who claim that family problems will interfere with learning by $45.8 \%$. Extrinsic motivation to learn affects the achievement of students (Anjomshoa \& Sadighi, 2015).

\section{CONCLUSION}

The result of this research shows that GPA which Timorese student achieved at all their study are $4 \%$ highest, $52 \%$ were high, $25 \%$ are medium and $19 \%$ are low. In regarding to the impact academic behavior, extrinsic learning motivation on academic achievement shown that academic behavior are $35.8 \%$ on academic achievement, Extrinsic leaning motivation are 54,1\% on academic achievement of Timorese student, who are studying in Indonesia. Therefore be discovered that academic achievement of Timorese student has been impacted by their academic behavior and extrinsic learning motivation.

\section{REFERENCES}

[1] Abdullah, M.Y, Bakar, A.R.A. \& Mahbob, M.H. 2012. Student's Participation in Classroom: What Motivates Them to speak up? Procedia - Social and Behavioral Sciences, (51), 516-522. Published by Elsevier Ltd. Faculty of Social Science \& Humanities, Universiti Kebangsaan Malaysia.

[2] Ahmar, F \& Anwar, E. 2013. Socio Economic Status and its Relation to Academic Achievement of Higher
Secondary School Students. IOSR Journal of Humanities and Social Science. (Online), 13(6), 13-20, (July-August, 2013) E-ISSN: 2279-0837, P-ISSN: 2279-0845. www.iosrjour-nals.org.

[3] Ali, N. J. K., Ali, S.M.N \& Salamt, Azni, S. A. 2009. The Factors Influencing Students' Performance at Universiti Teknologi Mara Kedah Malaysia. Canadian Research \& Development Center of Sciences \& Cultures, 3(4).

[4] Allensworth, E., \& Easton, J. Q. 2007. What Matters for Staying on-Track and Graduating in Chicago Public Schools. Chicago: University of Chicago Consortium on Chicago School Research.

[5] Anjomshoa, L \& Sadighi, F. 2015. The Importance of Motivation in Second Language Acquisition. International Journal on Studies in English Language and Literature (IJSELL), 3(2), 126-137, February 2015. ISSN 2347-3126 (Print) \& ISSN 2347-3134.

[6] Areepattamannil, S., Freeman, J. G., and Klinger, D. A. 2011. Academic Self-Concept, Academic Motivation, Academic Engagement, and Academic Achievement: A Mixed Methods Study of Indian Adolescents in Canada and India. Social Psychology Education, (14), 427-439. doi: 10.1007/ s11218-011-9155-1.

[7] Arnold, J. R. T., Chapman, S. N. \& Clive, L. M. 2008. Introduction to Materials Management. Pearson Education, Inc \& R.R. Donnelley \& Sons Company. USA, New Jersey: Upper Saddle River.

[8] Azwar, S. 2014. Psikologi Inteligensi. Yogyakarta: UGM.

[9] Biswal \& Aggarwal. 1971. Encyclopedia Dictionary and Directory of Education. New Delhi: Academic Publishers.

[10] Bulaklak, E. M. \& Pilobello, B. I. 2014. Observed Classroom Practices and Academic Behavior in Physical Education 1 of Freshman Psychology and Education Students. Asia Pacific Journal of Education, Arts and Sciences, 1(5).

[11] Cooper, H., Robinson, J. C. \& Patall, E. A. 2006. Does Homework Improve Academic Achievement? A Synthesis of Research, 1987-2003. Review of Educational Research, 76(1), 1-62.

[12] Covington, M. V., \& Mueller, K. J. 2001. Intrinsic Versus Extrinsic Motivation: An Approach/Avoidance Reformulation. Educational Psychology Review, 13(2), 157-176.

[13] Creswell, J. 2015. Riset Pendidikan: Perencanaan, Pelaksanaan, dan Evaluasi Riset Kualitatif dan Kuantitatif. Yogyakarta: Pustaka Belajar.

[14] Da Costa, A. 2015. Pengaruh Motivasi Belajar, Disiplin Belajar, dan Penyesuaian Diri Terhadap Prestasi akademik Mahasiswa Timor Leste yang Kuliah di Malang. Thesis. Malang: State University of Malang.

[15] Deci, E. L. \& Ryan R. M. 1985. Intrinsic Motivation and Self-Determination in Human Behavior. New York: Plenum.

[16] Deci, E. L. \& Ryan, R. M. 2000. Intrinsic and Extrinsic Motivation: Classic Definition and New Direction, Contemporary Educational Psychology, (25), 54-67.

[17] Deckers, L. 2005. Motivation: Biological, Psychological, and Environmental. Boston: Pearson.

[18] Depdiknas. 2008. Penataan Pendidikan Prosefional Konselor dan Layanan Bimbingan dan Konseling dalam Jalur Pendidikan Formal. Jakarta: Direktorat Jenderal Pendidikan Tinggi Departemen Pendidikan Nasional.

[19] Duckworth, A. L., \& Seligman, M. E. P. 2006. SelfDiscipline Gives Girls the Edge: Gender in Self- 
Discipline, Grades, and Achievement Test Scores. Journal of Educational Psychology (98), 198-208.

[20] Edgecombe, N. 2011. Accelerating the Academic Achievement of Students Referred to Developmental Education (CCRC Working Paper, 30, Assessment of Evidence Series). New York: Columbia University, Teachers College, Community College Research Center.

[21] Fahraeus, A. W. E. 2013. Learner-Centered Teaching: Five Key Changes to Practice (Review Book). Journal of the Scholarship of Teaching and Learning, 13(4), 16.

[22] Falsario, H. N., Muyong, R. F., and Nuevaespaña, J. S. 2014. Classroom Climate and Academic Performance of Education Students. Presented at the DLSU Research Congress 2014. De La Salle University, Manila, Philippines March 6-8.

[23] Farooq, M. S., Chaudhry A. H., Shafiq M., and Berhanu, G. 2011. Factors Affecting Students' Quality of Academic Performance: A Case of Secondary School Level. Journal of Quality and Technology Management, 7(2), 1-14.

[24] Farrington, C. A., Roderick, M., Allensworth, E., Nagaoka, J., Keyes, T. S., Johnson, D. W., \& Beechum, N. 2012. Teaching Adolescents to Become Learners. The Role of Non-cognitive Factors in Shaping School Performance: A Critical Literature Review. Chicago: University of Chicago Consortium on Chicago School Research.

[25] Fen, C. \& Kiat, P. 2015. A Review of Intrinsic and Extrinsic Motivations of ESL Learners. International Journal of Languages, Literature and Linguistics,1(2), June 2015. doi: 10.7763/IJLLL.2015.V1.20.

[26] Flashman, J. 2012. Academic Achievement and Its Impact on Friend Dynamics. American Sociological Association 2012. Sociology of Education, (85), 61-80.

[27] Ganai, M.Y., Mir M.A. 2013. A Comparative Study of Adjustment and Academic Achievement of College Students. Journal of Educational Research and Essays, 1(1), 5- 8.

[28] Garcia, R.A. \& Al-Safadi, L.A. 2014. Intervention Strategies for the Improvement of Students' Academic Performance in Data Structure Course. International Journal of Information and Education Technology, $4(5)$.

[29] Gijzen, H. 2014. Timor-Leste Unesco Country Programming Document 2009-2013. United Nation Educational, Scientific and Cultural Organization. Timor: Dili. Retrieved December 12, 2016, form http://unesdoc.unesco.org/images/0018/001852/ 185239e.pdf

[30] Governo Timor Leste. 2010. Timor-Leste Strategic Development Plan (PEDN) 2011 - 2030. Timor Leste: Dili.

[31] Hadi, S.P. 2012. Peraturan Rektor Universitas Diponegoro No.209/PER/UN7/ 2012. Semarang. Universitas Diponegoro.

[32] Hastuti, T. D. 2003, Pengaruh Kecerdasan Emosional dan Perilaku Belajar Terhadap Tingkat Pemahaman Akuntansi. Jurnal Akuntansi Bisnis, 2(3).

[33] Hilden, K., \& Jones, J. 2011. Rewards for Student Reading: A Good Idea or Not? Reading Today 29 (2), 6-7

[34] Hill. T. M. 2007. Classroom Participation this Paper was Completed and Sub-mitted in Partial Fulfillment of the Master Teacher Program, A 2-year Faculty Professional Development Program Conducted by the Center for Teaching Excellence, United States Military Academy. New York: West Point.
[35] Jacob, G. \& Small, J. 2003. Combining Dictogloss and Cooperative Learning to Promote Language Learning, 3(1). Retrieved December 9, 2016, from http://www.georgejacobs.net.

[36] Laguador, J.M. 2013. Developing Students' Attitude Leading Towards A Life-Changing Career. Educational Research International, 1(3).

[37] Levesque, C., Copeland, K. J., Pattie, M. D., \& Deci, E. L. 2011. Intrinsic and Extrinsic Motivation. In S. Järvelä (Ed.), Social and Emotional Aspects of Learning. Oxford, England: Academic Press.

[38] Lucas, M., Cabrita, I., and Ferreira, A. 2015. Pathways to Change: Improving the Quality of Education in Timor-Leste. Research Centre Didactics and Technology in Education of Trainers, Departement of Education, University of Aveiro, 3810-193 Aveiro, Portugal. Procedia - Social and Behavioral Sciences, 186, 732-738.

[39] McClelland, D.C. 1987. Human Motivation. New Year: Cambridge University Press.

[40] McGaha-Garnett, V. 2013. The Effects of Violence on Academic Progress and Classroom Behavior: From a Parent's Perspective - Ideas and Research You Can Use. USA: VISTAS.

[41] Mlambo, V. 2011. An analysis of some factors affecting student academic performance in an introductory biochemistry course at the University of the West Indies. Caribbean Teaching Scholar Educational Research Association, 1(2), 79-92.

[42] Mushtaq, I. \& Khan, S.N. 2012. Factors Affecting Students Academic Performance. Global Journal of Management and Business Research, 12(9), 1.

[43] Nugroho, P. I., Tanggulungan, G., \& Wibowo, B. O. B. 2011. Pengaruh Perilaku Belajar Terhadap Tingkat Pemahaman Akuntansi. Proceeding PESAT (Psikologi, Ekonomi, Sastra, Arsitektur dan Teknik).

[44] Parlamento. 2002. Constitution of the Democratic Republic of Timor-Leste. Dili: Parlamento Timor Leste.

[45] Peterson, C., \& Seligman, M. E. P. 2004. Character Strengths and Virtues: A Classification and Handbook. New York: Oxford University Press.

[46] Reutzel, D.R. \& Clark, S. 2011. Organizing Literacy Classrooms for Effective Instruction. The Reading Teacher, 65 (2): 96-109. DOI: 10.1002/TRTR. 01013 (C) 2011 International Reading Association.

[47] Riley, G. 2016. The role of Self-Determination Theory and Cognitive Evaluation Theory in Home Education. Educational Assessment \& Evaluation Research Article, 3, 28, March 2016.

[48] Rocca, K.A. 2010. Student Participation in the College Classroom: An Extended Multidisciplinary Literature Review Communication Education, 59(2), 185-213.

[49] Ryan, R. M., \& Deci, E. L. 2000. Intrinsic and Extrinsic Motivations: Classic Definitions and New Directions. Contemporary Educational Psychology, (2), 54-67.

[50] Shah, R. 2009. Timor-Leste Ten Years on: Reconstructing Curriculum for the Future? Faculty of Education, University of Auckland, Auckland, New Zealand. A Paper Presented at the 10th UKFIET Conference on Education and Development, Oxford, 15-17 September 2009, Retrieved December 9, 2016, from http://www.jndiario.com/2016/08/31/profes-sorestenke-jere-setor-edukasaun-didiak/com.

[51] Singh, K. 2011. Study of Achievement Motivation in Relation to Academic Achievement of Students. International Journal of Educational Planning \& Administration, 1(2), 161-171.

[52] Srisongkhram, W. 2014. The Effects of Learning Styles and other Psychological Variables on Predicting to 
Students Academic Achievement Based on Learning Evaluation Method in Adolescent Problem and Guidance Class. Silpakorn University Journal of Social Sciences, Humanities, and Arts, 14(3), 1-26.

[53] Thomas, P. 2005. Development Studies Network. Development Bulletin. Cooperating with Timor Leste. Australia: Cambera.

[54] Vallerand, R. J., Pelletier, L. G., Blais, M. R., Briere, N. M., Senécal, C., \& Vallieres, E. F. 1992. The Academic Motivation Scale: A Measure of Intrinsic, Extrinsic, and Amotivation in Education. Educational and Psychological Measurement, 52, 1003-1017. doi: 10.1177/00131644920 52004025.

[55] Vansteenkiste, M., Zhou, M., Lens, W., \& Soenens, B. 2005.. Experiences of Autonomy and Control Among Chinese Learners: Vitalizing or Immobilizing? Journal of Educational Psychology, (97), 468-483.

[56] Wang, J. H. \& Guthrie, J. T. 2004. Modeling the Effects of Intrinsic Motivation, Extrinsic Motivation, Amount of Reading, and Past Reading Achieve-ment on Text Comprehension between USA and Chinese Students. Reading Research Quarterly, 39(2), 162-186.

[57] Weimar, M. 2013. Learner-Centered Teaching: Five Key Changes to Practice. San Francisco: Jossey-Bass.

[58] Yahaya, N., Yahaya, A., Ramli, J., Hashim, S. Zakariya, Z. 2010 The Effects of Extrinsic Motivational Factors in Learning among Students in Secondary School in Negeri Sembilan. International Journal of Psychological Studies, 2(1).

[59] York, T.T., Gibson, C. \& Rankin, S. 2015. Defining and Measuring Academic Success. Practical Assessment, Research \& Evaluation, 20(5). 